\title{
LEUKOCYTE CHEMOTAXIS
}

\author{
By Abbas Emami, M.D.*
}

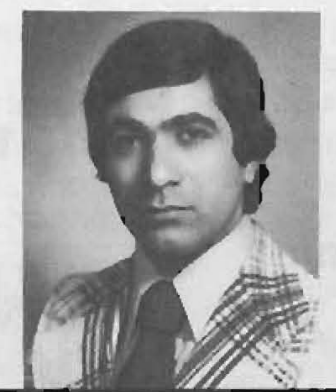

Bron on December 22, 1945 in Iran. Received M.D. degree from University of Tabriz School of Medicine, in July, 1971. Residency in Pediatrics and Fellowship in Pediatric Hematology/Oncology at Children's Hospital of Michigan, Detroit, Michigan (1976-1981).

Current Position: Instructor in Pediatrics, Department of Pediatrics, Wayne State University School of Medicine and Section of Hematology/Oncology, Children's Hospital of Michigan, Detroit, Michigan.

\section{INTRODUCTION}

The immune system is comprised of humoral and cellular components designed to protect the human body from the invasion of foreign materials. A major function of this complex system is to distinguish between self and nonself. The recognition of nonself under physiologic conditions leads to localization and ultimately destruction of invasive materials. Local accumulation of cells such as polymorphonuclear leukocytes (PMNs), macrophages, and lymphocytes is an integral part of host defense.' These cells can migrate in the direction of factors produced at the site of invasion, ingest and destroy the antigenic materials. A gradient of chemotactic activity is essential for this migration.2 The fragments of complement system (C5a. C3a, C567), kinins, fibrinogen, arachidonic acid oxidants, plasminogen. casein and bacterial products are among the known chemotactic factors capable of interacting with phagocytic cells. ${ }^{3}, 4$

Cell-ligand interaction takes place via receptors present on the cell surface. The cationic fluxes of $\mathrm{K}+$. $\mathrm{Na}+$ and $\mathrm{Ca}++$ following the cell-ligand interaction is considered essential for cell locomotion to the site. ${ }^{6}$ Further stimulus is provided through generation of chemotactic factors of the prostaglandin system. The generation of oxygen metabolites and secretion of lysosomal enzymes by cells facilitate the destruction of biologically active foreign materials. ${ }^{7}, *$

\section{METHODS}

Rebuck and Crowley in 1955 introduced a new in vivo technique for studying leukocyte locomotion. ${ }^{9}$ In this method, the epithelial layer of skin is scraped away to expose the papillary layer of the corium, providing a site of inflammation. A solution of inflammatory agent (e.g. typhoid toxoid) is applied to the denuded area and covered with a sterile coverslip. The cells which migrated to the site of inflammation attach to the coverslip. In performing this skin window test, the coverslips are removed at the designated time intervals and replace by new ones. The study of stained slides provide information regarding the types of cells and patterns of migration. This information has proven to be useful in studying leukocytic function in health and disease.

Boyden in $1962^{10}$ introduced an in virro method using a perspex chamber with two compartments, separated by a micropore filter. The lower compartment is filled with chemoattractant. The filter paper is placed on the floor of the upper compartment in contact with the chemotactic factor. The cell suspension is then added to the upper compartment and incubated. At the end of incubation, the filter is taken out and stained. The number of cells on the attractant side is counted and used to calculate the chemotaxis index.

Since the original description, this method has

* From the Section of Hematology/Oncology. Children's Hospital of Michigan and the Department of Pediatrics, Wayne State University School of Medicine, Detroit. Michigan 48201.

* At the time of his work, the author was a fellow of Children's Leukemia Foundation of Michigan. Reprint Requests: A. Emami. M.D., Children's Hospital of Michigan, Department of Hematology/Oncology, 3901 Beaubien, Detroit, Michigan 48201. 
endured changes and modifications. A number of new methods have also become available, which will be discussed, but the Boyden's chamber technique is still the most commonly used method in the study of leukocyte locomotion.

Gallin et al in 197311 used 51-chromium labelled granulocytes in a double filter Boyden chamber system for the assessment of leukocyte locomotion. The radioactivity of lower membrane containing cells migrated through upper filter membrane was used to quantitate cell migration. This method was used in a number of patients with humoral and cellular defects and proved to be both reliable and reproducible.

Cutler in $1974^{12}$ and Nelson et al in $1975^{13}$ reported another method of studying leukocyte function utilizing agarose in a petri dish instead of conventional chamber. The advantage of this method is that one can study the random migration, chemotaxis, and other related functions, as well as multiple sample materials, simultaneously.

Cell suspension is placed between chemoattractant, control medium, and other agents when indicated, in wells cut at predetermined distances in agarose and incubated. Quantitation of cell migration is done by measuring the linear distance the cells have migrated from the cell well toward the tested solution. One major difficulty encountered is diffusion pattern of solutions used in agarose mediu. With low molecular weight chemotactic factors, the diffusion can be so rapid that it can interfere with the migration of cells. ${ }^{4}$

Zigmond's development of a visual assay of leukocyte locomotion provided a method for "watching" cells react in real life manner under standard conditions. ${ }^{15}$ This method uses a very small amount of blood. The specimen is placed in a well cut in a plexiglass microscope slide. The test solution is pipetted in another well separated from cell containing well by a one millimeter bridge. When the wells are covered wth a coverslip, the fluid in the wells will be drawn by capillary action over the bridge. The locomotion of cells can be directly visualized using a microscope, and recorded by time-lapsed videotape photography.

\section{CHEMOTACTIC FACTORS}

The known chemotactic factors present in the human system were briefly discussed in the introduction. Here, an effort will be made to discuss the use of chemotactic factors in vitro for the study of leukocyte locomotion.

It is now well established that certain peptides and lipids can attract leukocytes under controlled conditions in vitro. Wilkinson suggested that the hydrophobicity of these factors is the major determinant of their chemotactic activity. " Bacterial chemotactic factors are widely used chemotactic lipids. ${ }^{17}$ Escherichia coli is a popular bacterium used for this purpose. Thirty-six to forty-eight hours culture of E-coli is usually adequate for sufficient growth. Filtrate of the medium contains potent chemotactic substance which is diluted to desired concentration for use. A class of lipid chemoattractants to mention here is hydroxyeicosatetraenoic acid (HETE). ${ }^{18}$ HETE is generated from arachidonic acid oxidation by the action of lipoxygenase. Lymphokines are another class of chemoattractants for PMNs, monocytes, eosinophils, basophils, and lymphocytes. The best defined factor is known as Lymphocyte Derived Chemotactic Factor (LDCF). This small molecular weight protein is produced by both $\mathrm{T}$ and $\mathrm{B}$ lymphocytes. and is not derived from the complement system. Abnormalities in the synthesis of lymphokines have been found in Wiskett-Aldrich syndrome, chronic mucocutaneous candidiasis, and Hodgkin's disease. ${ }^{19}$ Zymosan activated serum, by means of activation of complement system and production of frangment $\mathrm{C} 5 \mathrm{a}$, is another source to be used as chemotactic factor.

The introduction of synthetic polypeptides by Schiffman and co-workers in 1975, provided a new category of chemotactic factors with broad applications. ${ }^{20}$ The demonstration of specific receptors for peptide chemotactic factors is an example of this contribution. While studying the characteristics of chemotactic factors produced by bacteria, these investigators isolated a low molecular weight, heat-stable peptide. The chemical similarities between material discovered and formylmethionyl peptides prompted the use of the latter for chemotactic experiments and proved to be a potent attractant. $\mathrm{N}$-formylmethionylleucylphenylalanine is the most widely used member of this family, and is a highly effective chemoattractant at concentrations of as low as $1 \times 10-11 \mathrm{M}$. These peptides are also capable of inducing lysosomal release.

\section{AUTHOR'S METHOD}

The method utilized by the author is described in detail here. The following materials are needed:

1) Neuro Probe Blind Well Boyden chamber, \#441200 (Nuclepore).

2) Micropore filter. $\# 150412,13 \mathrm{~mm}$ diameter, $3 \mathrm{~m}$ pore size (Nuclepore).

3) Hank's Balanced Salt Solution (HBSS) $1 \mathrm{x}$ (prepared by mixing $10 \mathrm{ml}$ HBSS $10 \mathrm{x}$, \#3104060 (GIBCO). $3 \mathrm{ml}$ HEPES Buffer, $\$ 380-5630$ (GIBCO), and $87 \mathrm{ml}$ sterile distilled water). $\mathrm{pH} 7.2$.

4) $\mathrm{N}$-formylmethionylleucylphenylaianine (FMLP). \#F-6004 (Sigma), 10-7 M-10-8 M (prepared by dissolving FMLP in Dimethyl- 
sulfoxide to $10^{-4} \mathrm{M}$ and further dilution with

HBSS Ix to desired concentration), pH 7.2.

Venous blood is collected in syringe containing. $1 \mathrm{ml}$ of 1000 units $\mathrm{ml}$ heparin for each $10 \mathrm{ml}$ whole blood. The specimen is gravity or dextran sedimented. The leukocyte rich plasma is then centrifuged at $800 \mathrm{rpm}$ for 10 minutes. Plasma is separated and saved for experiment. The cell pellet is washed $2-3$ times, adding $5 \mathrm{ml}$ HBSS $\mathrm{lx}$, resuspending the cells and centrifuged for 5 minutes. Washed cells are suspended in small amount of HBSS $I x$ and a cell count and differential is performed. Final concentration of cells, usually $1 \mathrm{x}$ $10^{4}$, is made by further addition of HBSS Ix, plasma or serum, or other desired test solutions.

The lower well of the chemotactic chamber is filled with pre-determined amount of chemotactic factor, or desired solution. The volume should be calibrated and standardized for each batch of chambers with micropipette to deliver precise volume of fluids. This will eliminate fluctuations in delivered volumes that give erroneous results by leakage of fluid to the upper compartment or insufficient contact of membrane and solution. The filter paper is placed on the floor of the upper compartment. There should not be any air bubbles trapped under the membrane. Then, the screw cap is replaced and tightened slightly. Finally, the cell suspension. usually in the amount of $0.2 \mathrm{ml}$, is pipetted to the upper well and incubated in humid air with $7 \%$ $\mathrm{CO} 2$ for 45 minutes. All experiments are done in triplicate. At the end of the incubation, the membranes are removed and placed on coverslips, attractant side up. After allowing the filters to dry for 60 minutes, staining is carried out using Wright's stain. The stained filters are then removed and placed on microscope slides with cells facing up and air dried. Dried filters are covered with a drop of Permount and coverslip and evaluated. The average of cells counted on ten random fields using oil magnification (usually $8 \times 40$ is used as chemotaxis index).

Following is an example of the comparison of chemotactic index and random migration using FMLP $\left(10-^{x} \mathrm{M}\right)$ and HBSS $\mathrm{x}$ in a normal individual. Experiments were done on three different occasions, and the numbers represent average of triplicate specimens.

$\begin{array}{lccc}\text { Day } & \text { Upper compartment* } & \text { Lower compartment } & \text { Mean } \\ 1 & \text { A.E. cells/HBSS } & \text { FMLP } & 79.25 \\ 2 & \text { A.E. cells HBSS } & \text { HBSS } & 14.95 \\ 2 & \text { A.E. cells HBSS } & \text { FMLP } & 66.50 \\ 3 & \text { AE cells HBSS } & \text { HBSS } & 13.45 \\ & \text { AE cells HBSS } & \text { FMLP } & 81.50 \\ & \text { AE cells HBSS } & \text { HBSS } & 14.75\end{array}$

* $0.2 \mathrm{ml}$ of cell suspension, final concentration of $1 \times 10^{6}$ cells $/ \mathrm{ml}$.

\section{CLINICAL APPLICATIONS}

The methods discussed in this paper, both in vivo and in vitro, have enabled the investigators to study a wide variety of disorders suspected of having leukocyte chemotactic defect. In this process. new disorders have been discovered. It is now apparent from extensive studies that defects in chemotaxis can be due 10 one or a combination of several conditions. ${ }^{21},{ }^{22},{ }^{23}$ :

(1) Abnormalities of immune recognition (e,g. defective activation of complement system. immunoglobulin deficiencies); (2) defects in the production of chemotactic factors (e.g. abnormalities of complements, defective kinin generation): (3) inactivation of chemotactic factors (e.g. Hodgkin's disease, cirrhosis, sarcoidosis. lepromatous leprosey. systemic lupus erythematosus, anergy): (4) inhibition of phagocytic cells by antagonists (e.g. recurrent infections, hyperimmunoglobulin $\mathrm{E}$ and $\mathrm{A}$,, drug therapy, Wiskott-Aldrich syndrome, rheumatoid arthirtis); and (5) intrinsic cellular defects (c.g. defects related to: Cell deformability in neonates and Chediak-Higashi syndrome; adherence in diabetes mellitus: random migration in lazy leukocyte syndrome: chemotaxis in hyper $\mathrm{IgE}$ and $\mathrm{A}$. hypogammaglobulinemia, bone marrow transplantation, idiopathic juvenile periodontitis. Down's syndrome SLE).

Defective chemotaxis results in recurrent infections, as seen in disorders mentioned. This association is under intense investigation with the hope of finding treatment options. In this context, any study of leukocyte chemotaxis must cover both cellular and humoral aspects and this must be done with considerations given to the whole patient and the host defense mechanisms. 


\section{REFERENCES}

1. Snyderman. R.. Pike. M.C.: Disorders or Leukocyte Chemotaxis. Ped. Clin. Norh Amer. 1977.24(2):377393.

2. Zigmond. S.H.: Mechanism of sensing Chemical Gradients by Polymorphonuclear l eukocytes. Narure. 1974. $249: 450-452$.

3. Bachner, R.L.: Neutrophil Dysfunction Associated with States of Chronic and Recurrent Infections. Ped. Clin. North Am. 1980, 27: 377-401.

4. OFlaherty, J.T. Ward. P.A.: Chemotactic Factors and the Neutrophil. Semin Hematol. 1979. 16(2): 163 174.

5. Marasco, W.A.. Becker, E.L.. Oliver, J.M.: The lonic Basis of Chemotaxis. Am. J. Pathol., 1980, 98(3): 749 764 .

6. Ward, P.A.: Personal Communication, 1981.

7. Gallin, J.1., Wright. D.G. Malech, H.L., Davis, I.M., Klempner. M.S.. Kirkpatrick. C.H.: Disorders of Phagocyte Chemotaxis. Anm. In. Med. 1980. 92:520538.

8. Becker, E.L.: Chemotaxis. J. Allergy Clin Immumol.. 1980. 66(2): 97-105.

9. Rebuck. J.W.. Crowley, J.H.: A Method of Studying Leukocyte Functions in vivo. Amn. N.Y. Acad. Sci. 1955. 59: 757-805.

10. Boyden, S.: The Chemotactic Effect of Mixtures of Antibody and Antigen on Polymorphonuclear Leukocytes. J. Exp. Med., 1962, 115: 453-466.

11. Gallin, J.I.. Clark. R.A.. Kimball, H.R.: Granulocyle Chemotaxis: An Improved In Virro Assay Employing ${ }^{51} \mathrm{Cr}$-labelled Granulocytes. I. Immumol. 1973. 110 : 233-240

12. Cutler. I.E.: A Simple In Vitro Method for Studies on Chemotaxis. Proc: Soc. Exp. Biol. Med. 1974, 147: $471-474$.

13. Nelson. R.D., Quie. P.G.. Simmons, R.L.: Chemotaxis Under Agarose: A New and Simple Method for Measuring Chemotaxis and Spontaneous Migration of Human Polymorphonuclear Leukocytes and Monocytes. J. Immunol., 1975, I15: 1650-1656.

14. Nelson. R.D.: Discussion, in: Gallin, 1.1. Quie, P.G. (eds). Leukocyte Chemotaxis: Methods, Physiology and Clinical Implications. New York: Raven Press. 1978: pp. 40-42.

15. Zigmond, S.H: A New Visual Assay of Leukocyte Chemotaxis, in: Gallin. J.I.. Quie. P.G. (eds).Leukocre Chemoraxis: Methods. Physiology and Clinical Implications. New York: Raven Press. 1978. pp. 57-64.

16. Wilkinson. P.C.: Recognition and Response in Mononuclear and Granular Phagocytosis. Clin. Exp. lmmmol. 1976, 25: 355

17. Ward. P.A. Lipow. 1.H. Newman, L.J.: Bacterial Factors Chemotactic for Polymorphonuclear Leukocytes. Am. I. Pathol. 1968, 52: 725-736.

18. Turner, S.R.. Lyn, W.S.: Lipid Molecules as Chemotactic Factors, in: Gallin, J.1. Quie, P.G. (eds). Leukocyte Chemotaxis: Methods. Phvsiology and Clinical Implicarions. New York: Raven Press. 1978: pp. 289-296.

19. Altman, L.C.: Chemotactic Lymphokines: A review, in: Gallin, J.I.. Quic. P.G. (eds). Leukocyte chemotaxis: Methods, Physiology and Clinical Implicarions. New York: Raven Press, 1978, pp. 267285.

20. Schiffmann, E. Corcoran, B.A., Wahl, S.M.: Nformylmethionylpeptides as Chemoatractants for Leukocytes. Proc. Natl. Acad. Sci. USA, 1975, 72 : 1059-1062.

21. Gallin, I.I. Wright, D.G., Malech, H.L. Davis, J.M. Klempner. M.S. Kirkpatrick. C.H.: Disorders of Phagocyte Chemotaxis. Am In Med.. 1980, 92: 520538

538 .

22. Snyderman. R.. Pike. M.C.: Disorders of Leukocyte Chemotaxis. Ped. Clin. North Am. 1977. 24(2): 377393.

23. O'Flaherty, J.T. Ward, P.A.: Chemotactic Factors and the Neutrophil. Sem. Hematol., 1979. 16(2): 163-174. 